\title{
Synovial sarcoma of the neck
}

\section{Boyunda görülen sinoviyal sarkom olgusu}

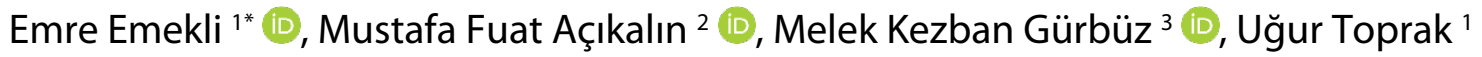 \\ ${ }^{1}$ Eskisehir Osmangazi University Faculty of Medicine, Department of Radiology, Eskişehir, Turkey \\ ${ }^{2}$ Eskisehir Osmangazi University Faculty of Medicine, Department of Pathology, Eskişehir, Turkey \\ ${ }^{3}$ Eskisehir Osmangazi University Faculty of Medicine, Department of Otorhinolaringology, Eskişehir, Turkey \\ * Corresponding author: Emre Emekli E-mail: emreemekli90@gmail.com ORCID: 0000-0001-5989-1897 \\ Received: 30 August 2019 Accepted: 15 October 2019
}

\begin{abstract}
Synovial sarcomas are rare malignant neoplasms commonly arising from articular tendons and joint capsules. Despite being termed synovial sarcomas due to their histologic similarity to the synovium, they rarely involve a synovial structure. Although they mostly occur in lower extremities, rare cases originating from the thorax, abdomen, head, and neck have also been reported. A 60-year-old male patient was admitted to the hospital with a complaint of swelling in left side of the neck. CT revealed a mass of approximately $6.5 \times 5 \mathrm{~cm}$, occupying the left parapharyngeal space and left submandibular fossa and protruding into the pharynx lumen. The lesion was non-infiltrative, well circumscribed, and uniformly ovoid. The patient underwent surgery, and subsequent pathological examination confirmed the diagnosis of synovial sarcoma. Despite their rarity, synovial sarcomas should be considered, along with Ewing's sarcoma, rhabdomyosarcoma, and other sarcomas, in the differential diagnosis of a large juxtaarticular mass containing calcifications.
\end{abstract}

Keywords: synovial sarcoma, computed tomography, jugulodigastric space, neck

\section{öz}

Sinoviyal sarkomlar artiküler tendonlardan ve eklem kapsüllerinden köken alan nadir malign tümörlerdir. Histolojik olarak sinoviyuma benzerlikleri nedeniyle sinoviyal sarkom olarak isimlendirilmelerine rağmen, nadiren sinoviyal yapı içerirler. Genellikler alt ekstremitede görülmekle birlikte nadir olarak toraks, abdomen, baş-boyun bölgesinde sinoviyal sarkom tespit edilen olgular bildirilmiştir. 60 yaşında erkek hasta boyun sol yarısında şişlik şikayeti ile hastanemize başvurdu. Çekilen bilgisayarlı tomografide sol parafaringeal boşluğu ve sol submandibular fossayı doldurup, farenk lümenine protrude yaklaşık $6,5 \times 5 \mathrm{~cm}$ boyutunda kitle tespit edildi. Kitle düzgün sınırlı, ovoid şekilli ve çevre dokulara infiltrasyon göstermemekteydi. Cerrahi olarak total çıkarılan kitlenin histopatolojik tanısı sinovyal sarkom olarak belirlendi. Nadir görülmelerine rağmen sinoviyal sarkomlar Ewing sarkomu, rabdomiyosarkom ve diğer sarkomlarla birlikte kalsifikasyon içeren jukstaartiküler kitlelerin ayırıcı tanısında düşünülmelidir.

Anahtar kelimeler: sinoviyal sarkom, bilgisayarlı tomografi, jugulodigastric boşluk, boyun

() 2020 by the authors; licensee MEDITAGEM Ltd., Turkey. This article is an open access article distributed under the terms and conditions of the Creative Commons Attribution License (http://creativecommons.org/licenses/by/4.0/). 


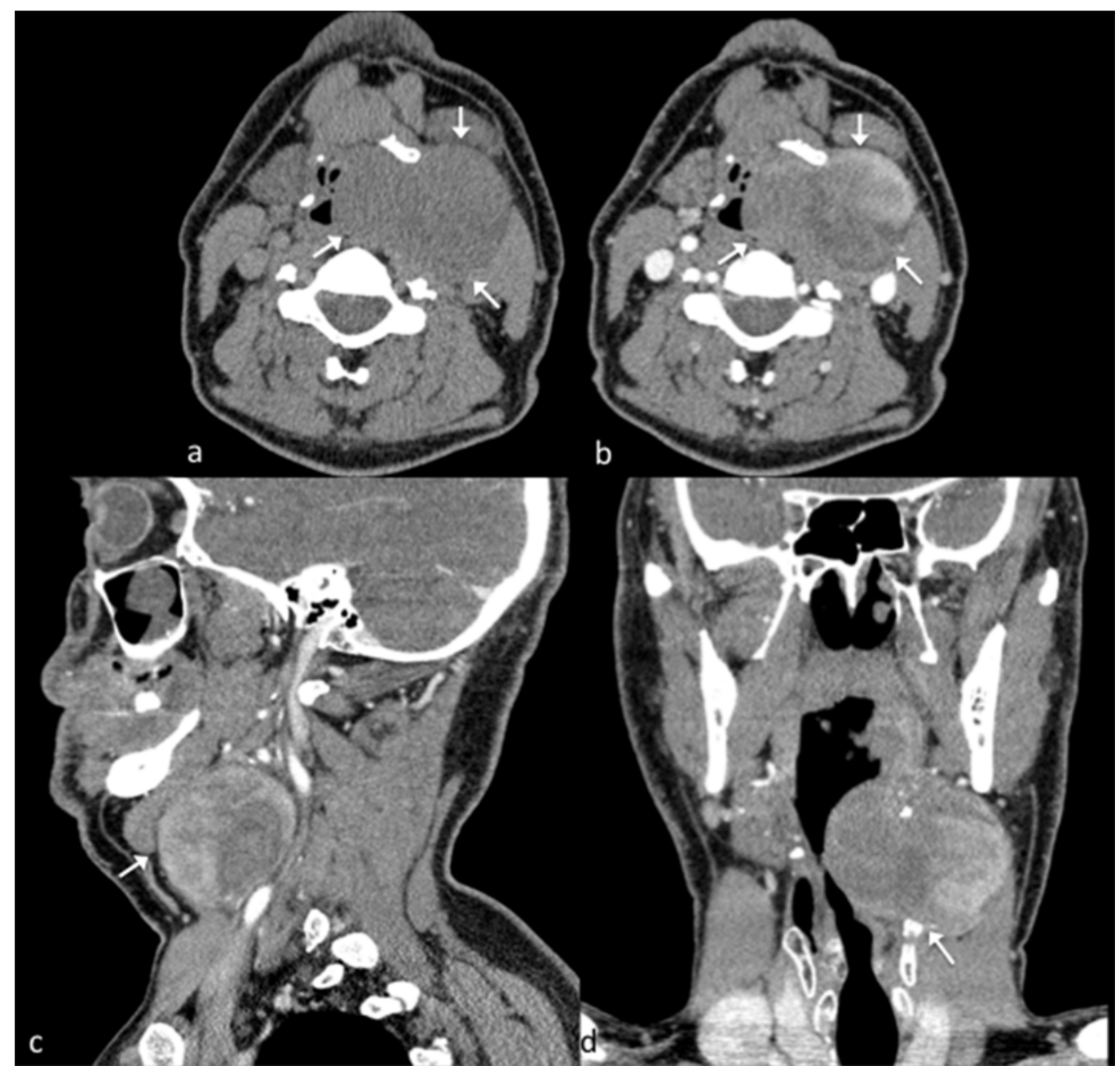

Figure 1. Synovial sarcoma of the jugulodigastric region visualized on (a) unenhanced and (b) enhanced axial, sagittal and coronal CT slices. The lesion, involving the left jugulodigastric region, is protruding into the larynx. It is located beneath the submandibular gland and above the thyroid cartilage. Some parts of the lesion show better contrast enhancing

\section{INTRODUCTION}

Synovial sarcoma is a rare malignant neoplasm that commonly arises from articular tendons and joint capsules; however, the synovial relationship is not always clear. Synovial sarcoma is the third most common soft tissue sarcoma in adults and accounts for approximately $10 \%$ of soft tissue sarcomas [1,2]. Despite being termed synovial sarcomas due to their histologic similarity to the synovium, they rarely involve a synovial structure and are usually seen near the joints [3], mostly affecting the extremities. Although they generally occur in the lower extremities, rare cases originating from the thorax, abdomen, head, and neck have also been reported. About $9 \%$ of synovial sarcomas are located in the head and neck region. Synovial sarcomas are usually seen in adolescents and young adults. Most studies have shown that the median age of synovial sarcomas is in the third decade and approximately $66 \%$ of the patients are male. Synovial sarcoma in the head and neck region is mostly located in the hypopharynx, the parapharyngeal space, and postpharyngeal region [4].
This case is presented because it is a rare lesion that is usually overlooked in the differential diagnosis of neck solid lesions.

\section{CASE}

A 60-year-old male patient was admitted to the hospital with a complaint of swelling in the left side of the neck. On physical examination, a mass of approximately $3 \times 3 \mathrm{~cm}$ was palpated in the left jugulodigastric area. Ultrasonography revealed a heterogeneous echogenic mass of about $5 \mathrm{~cm}$ in diameter on the left side of the neck. The patient was then evaluated with neck CT.

There was a mass approximately $6.5 \times 5 \mathrm{~cm}$ in size, occupying the left parapharyngeal space and left submandibular fossa and protruding into the pharynx lumen. The defined mass was observed as hypodense from the surrounding muscle tissue in the unenhanced CT examination. The lesion was non-infiltrative, well circumscribed, and uniformly ovoid. On contrast-enhanced $\mathrm{CT}$, the anterolateral segment showed more contrast enhancement than the posterior (Figure 1). 


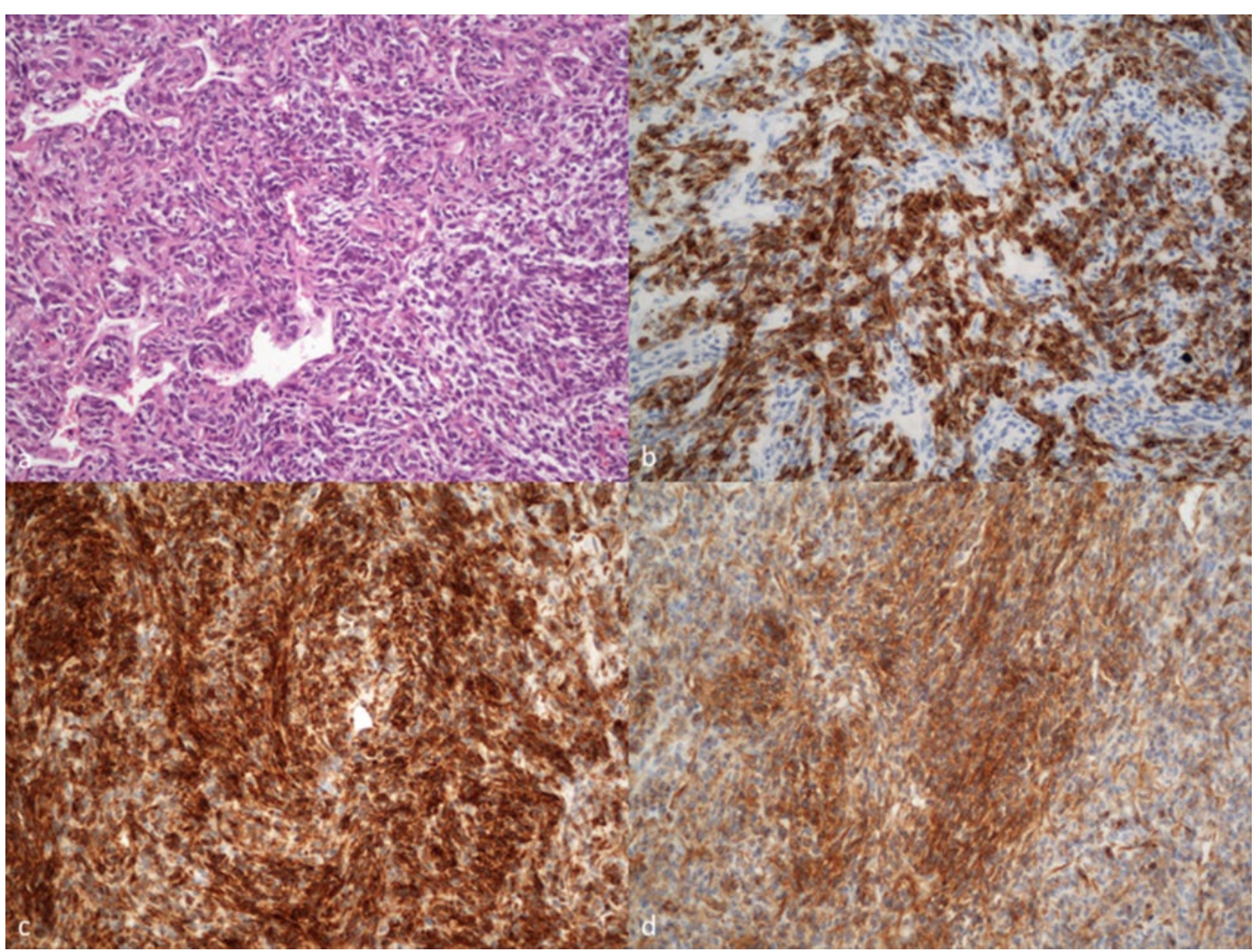

Figure 2. (a) Uniform spindle cells and hemangiopericytomatous vasculature (H\&Ex200), (b) Cytokeratin AE1/AE3 positivity in tumor cells (x200), (c) Strong immunoreactivity for bcl2 protein in tumor cells (x200), and (d) CD99 positivity in tumor cells (x200)

The lesion was totally resected. The pathological outcome was reported as synovial sarcoma (Figure 2).

\section{DISCUSSION}

In the differential diagnosis of tumors in the digastric area, cystic lesions, such as brachial cleft cysts and lymphangioma, metastatic lymph nodes, and salivary gland tumors need to be considered [5]. In the present case, there was no cystic component, and the mass was purely solid. Therefore, branchial cleft cysts and lymphangioma were not considered in the differential diagnosis.

Salivary gland tumors that usually originate from the parotid gland tail should also be considered in the differential diagnosis of lesions located in the jugulodigastric area. Pleomorphic adenomas are the most common salivary gland tumors. Pleomorphic adenomas are usually visualized as spherically shaped, hypodense masses with lobulated contours. Necrotic areas and calcification may also be detected. The contrast agent enhances smaller tumors to a greater extent than larger tumors [6]. Another common benign salivary gland tumor is Warthin's tumor, which is usually divided into multifocal and bilateral tumors. Warthin's tumors are seen bilaterally and multifocally and differ from other lesions with their well-defined, homogeneous and generally lobulated structure. They may be solid or may contain cystic components. These tumors have moderate enhancing on CT [7]. However, in the present case, the contour feature, shape and contrast pattern of the lesion were different.

Adenoid cystic carcinoma and mucoepidermoid carcinoma are the two most common malignant salivary gland tumors, with the other examples of this group being acinar cell cancer and squamous cell cancer. Malign lesions tend to be smaller and are seen more rarely. On contrast-enhanced CT, low-grade lesions are visualized as masses with cystic and solid components. Aggressive tumors are mostly solid masses with irregular borders. High-grade lesions may invade the surrounding tissues and involve the external jugular vein or cause the narrowing of the carotid artery [8]. In the present case, the lesion was purely solid, and there was no evidence of the invasion of the surrounding tissue.

Another group of tumors that should be considered in differential diagnosis are metastatic lymph nodes. The jugulodigastric node is the first lymph node to receive lymphatic drainage from the tonsils, pharynx, mouth, and face. Pathological lymph nodes can be seen in the jugulodigastric area, especially in the tonsils, pharynx mouth, and facial tumors [9]. Vascular lesions, lymphoproliferative diseases, lymphoma, and sarcomas may 
also be present in this region. However, neurogenic tumors and sarcomas are rarely observed in this area [5].

Although synovial sarcomas took their name from their similarity to the synovium, they are considered to originate from primitive mesenchymal cells that undergo differentiation to synovial cells. The main histologic variants of these sarcomas are: a biphasic type consisting of spindle and epithelial cells that usually form glandular structures, a monophasic type consisting of only spindle cells, and a poorly differentiated type consisting of cells that resemble small, round, blue cells. The monophasic variant is the most common among these histopathological types. Synovial sarcoma is associated with a specific $t(X ; 18)$ ( $p 11 ; q 11)$ translocation, involving SS18 (SYT), SSX1, SSX2, or SSX4. The characteristic pathologic features of synovial sarcoma include tumoral calcification, cystic changes, and necrosis [10].

The most common CT appearance of synovial sarcoma is that of a heterogeneous deep-seated soft-tissue mass. The CT attenuation of synovial sarcomas are similar to or slightly lower than that of muscle and lower attenuation areas, and necrosis and hemorrhage are also common [12]. A contrastenhanced CT scan shows heterogeneous enhancement in $89 \%-100 \%$ of cases, but smaller lesions may be more homogeneous [11]. CT is also useful for detecting calcification and bone involvement in synovial sarcoma. This technique typically reveals a non-infiltrative, wellcircumscribed soft tissue mass. Although punctate, peripheral calcifications are other entities identified in most CT images [13], we did not observe them in our case; the lesion was non-infiltrative, well-circumscribed, and uniformly ovoid and showed heterogeneous enhancement.

$M R I$ is the modality of choice for the diagnosis and initial staging of synovial sarcoma because of the information provided by intrinsic signal characteristics and superior softtissue contrast [14]. On T1-weighted MR images, synovial sarcoma appears as a prominently heterogeneous multilobulated soft tissue mass with signal intensity similar to or slightly higher than that of muscle. Prominent heterogeneity with predominant high signal intensity is also a feature of these lesions on T2-weighted MR images. In addition, a triple signal pattern, representing the hypointense, isointense, and hyperintense areas on T2weighted images, is typically seen. This heterogeneity and triple sign on T2-weighted MR images is the result of a mixture of solid cellular elements, hemorrhage, necrosis, and calcified or fibrotic collagenized regions [11]. In the present case, an MRI scan was not performed since the lesion was well-circumscribed and the $\mathrm{CT}$ images were considered adequate for surgery.

\section{CONCLUSION}

Despite being rare tumors, synovial sarcomas should be considered, along with Ewing's sarcoma, rhabdomyosarcoma, and other sarcomas, in the care of young adults and adolescents with a large juxtaarticular mass containing calcifications. CT and MRI each have their own advantages in evaluation, and the combination of the two approaches can improve the accuracy of the diagnosis. Considering the slowly progressing nature of synovial sarcomas, in the early stage when clinical findings are not sufficient, imaging modalities are the only way of achieving early diagnosis. However, the final diagnosis relies on the results of a pathological investigation.

\section{DECLARATION OF CONFLICT OF INTEREST}

The authors received no financial support for the research and/or authorship of this article. There is no conflict of interest.

\section{REFERENCES}

1. Brennan MF, Antonescu CR, Moraco N, Singer S. Lessons learned from the study of 10,000 patients with soft tissue sarcoma. Annals of surgery. 2014;260(3):416-21.

2. Brennan MF, Singer S, Maki RG. Sarcomas of the soft tissues and bone. In: Devita V, Hellman S, Rosenberg SJNYL. Cancer: principles and practice of oncology, 7th. 2005:1584.

3. Kransdorf MJ. Malignant soft-tissue tumors in a large referral population: distribution of diagnoses by age, sex, and location. AJR American journal of roentgenology. 1995;164(1):129-34. (doi:10.2214/ajr.164.1.7998525).

4. Koga C, Harada H, Kusukawa J, Kameyama TJOOE. Synovial sarcoma arising in the mandibular bone. 2005;41(3):45-8. (doi: 10.1016/j.ooe.2004.11.001).

5. Jung Jl, Kim HH, Park SH, Lee YS. Malignant ectopic thymoma in the neck: a case report. AJNR American journal of neuroradiology. 1999;20(9):1747-9.

6. Kakimoto N, Gamoh S, Tamaki J, Kishino M, Murakami S, Furukawa S. CT and MR images of pleomorphic adenoma in major and minor salivary glands. European journal of radiology. 2009;69(3):464-72. (doi: 10.1016/j.ejrad. 2007.11.021). 
7. Yao H, Lin H, Zhang P, Zhang T, Feng LJTC-GJoCO. CT and MRI findings of parotid Warthin's tumors. 2011;10(10):596. (doi: 10.1007/s10330-011-0845-0).

8. Gökaslan ÇO, Toprak U. Parafaringeal Bölge Radyolojisi. Turkiye Klinikleri Ear Nose and Throat-Special Topics. 2017;10(2):120-7.

9. Som PM, Brandweine-Gensler MS. Lymph nodes of the neck. In: Som PM, Curtin HD. Head and Neck Imaging EBook: Elsevier Health Sciences 5th; 2011:2287-378.

10. Eilber FC, Dry SM. Diagnosis and management of synovial sarcoma. J Surg Oncol 2008;97:314-20. (doi: 10.1002/jso.20974).
11. Murphey MD, Gibson MS, Jennings BT, Crespo-Rodríguez AM, Fanburg-Smith J, Gajewski DAJR. Imaging of synovial sarcoma with radiologic-pathologic correlation. 2006;26(5):1543-65. (doi: 10.1148/rg.265065084).

12. Kransdorf MJ, Murphey MD. Imaging of soft tissue tumors. 2nd ed. Philadelphia: Lippincott William \& Wilkins 2006.

13. Nakanishi H, Araki N, Sawai Y, Kudawara I, Mano M, Ishiguro $S$, et al. Cystic synovial sarcomas: imaging features with clinical and histopathologic correlation. 2003;32(12):701-7. (doi: 10.1007/s00256-003-0690-5).

14. Bakri A, Shinagare AB, Krajewski KM, Howard $S A$, Jagannathan JP, Hornick JL, et al. Synovial sarcoma: imaging features of common and uncommon primary sites, metastatic patterns, and treatment response. 2012;199(2):W208-W15. (doi: 10.2214/AJR.11.8039). 